
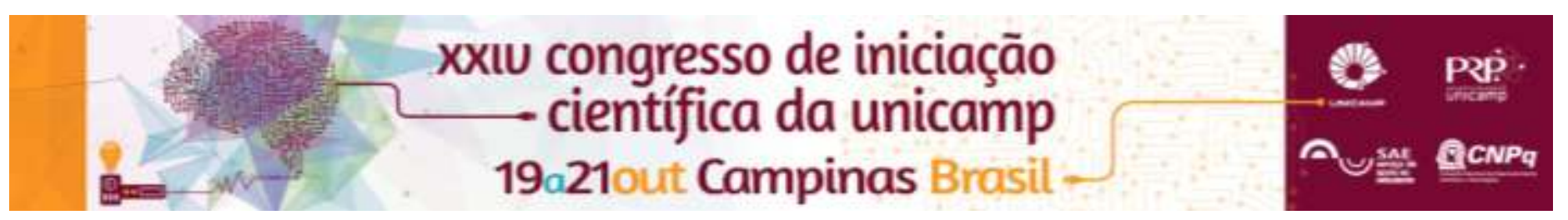

\title{
Olhai os lírios do campo e o sucesso imprevisível
}

\section{Talita de Almeida Costa (IC)}

\section{Resumo}

O presente trabalho teve como objetivo investigar, por meio de pesquisas em jornais das décadas de 1930 e 1940 e de uma leitura detalhada do romance Olhai os lírios do campo, de Erico Verissimo, os motivos internos e externos que o levaram a se tornar o maior sucesso editorial da época.

\section{Palavras-chave: Olhai os lírios do campo, Erico Verissimo, romance de 30.}

\section{Introdução}

A presente pesquisa teve como objetivo principal compreender os motivos que levaram Olhai os lírios do campo, quinto romance de Erico Verissimo, a tornar-se o primeiro sucesso nacional de vendas, com 527 exemplares vendidos nos cinco primeiros dias, caindo no gosto do público brasileiro como nenhum outro romance de autor nacional havia feito. Para isso, foi feita a busca e a análise de artigos de jornais das décadas de 1930 e 1940, seguidas de uma leitura bastante próxima do romance. Assim, com base em elementos internos e externos a ele, foi possível concluir a importância do romance de Verissimo para os leitores da época e, por extensão, para a literatura brasileira.

\section{Resultados e Discussão}

Para a primeira parte da pesquisa, foram coletados artigos de jornais e revistas populares que apresentavam informações sobre Olhai os lírios do campo, seu enredo e seu sucesso com o público. Foram encontrados, no total, 30 menções a ele em 10 publicações diferentes, datadas entre 1938 e 1949. Tais menções foram classificadas de acordo com o teor das opiniões apresentadas, como mostra a Tabela 1.

Tabela 1. Número de menções ao livro encontradas nos jornais, separados pelo teor das opiniões expressas.

\begin{tabular}{|c|c|c|}
\hline Opiniões & Total & $\%$ \\
\hline Positivas & 19 & 63,3 \\
\hline Intermediárias & 2 & 6,6 \\
\hline Negativas & 2 & 6,6 \\
\hline Neutras & 7 & 23,3 \\
\hline
\end{tabular}

Por meio dessa busca, foi possível mapear as principais opiniões de jornalistas populares sobre o romance, que incluem a grande necessidade de Cristo demonstrada pelo narrador, que ao mesmo tempo não apresenta ares de cartilha moral; a sua capacidade de estudar a alma humana como ninguém; a maestria em unir o social e o moral; e, principalmente, sua eficiência em dar ao público aquilo que ele vive, e, também, aquilo que ele deseja. Tais características seriam a prova de que existem, no romance, "certas relações secretas entre a obra e seu público" (CARPEAUX, 1972), que foram examinadas, na segunda parte da pesquisa, por meio da leitura analítica do romance. Durante essa leitura, foi possível encontrar alguns fatos que parecem ter sido responsáveis pela identificação dos leitores com 0 enredo e seus personagens. $O$ ponto central é a trajetória de Eugênio Fontes, que passa do desejo infantil de bondade para o materialismo de homem traumatizado pela pobreza, sendo seduzido pela possibilidade de grandeza. Aos 30 anos, ele percebe que a felicidade não está onde ele imaginava encontrá-la, e percorre um caminho de redenção, repleto de renúncias, para encontrar a felicidade junto à humanidade e à religiosidade. Tal percurso não se abstém de críticas sociais, como relatava o julgamento de alguns críticos e escritores apegados ao romance social, mas constrói uma relação entre as mazelas sociais e as aflições do espírito, de forma a mostrar que as injustiças do mundo são causadas pelo egoísmo e a falta de amor ao próximo, e que podem ser solucionadas, idealmente, em um futuro no qual as relações humanas deixem de ser esmagadas pela ganância e o egoísmo.

Figura 1. Anúncio da $5^{\underline{a}}$ edição de Olhai os lírios do campo, no Diário de Notícias (27 jun. 1939).

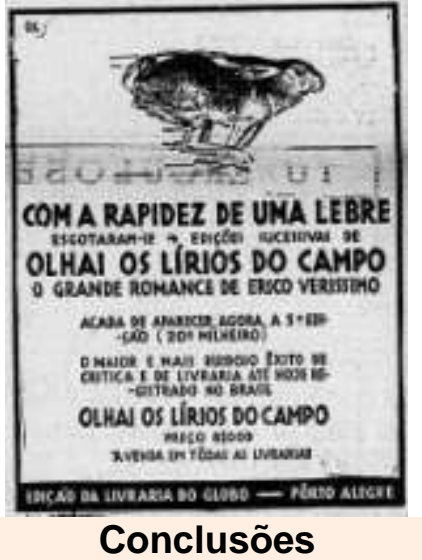

Ao tratar de problemas do espírito e estudar a alma humana, sem ignorar as mazelas sociais que tanto tiveram destaque no romance brasileiro da década de 30 , Erico Verissimo falou ao corpo e à alma dos leitores brasileiros, produzindo um romance profundamente humano que marcou a história do mercado editorial brasileiro e provou que o que efetivamente perpetua 0 êxito de uma obra literária é o público que ela atinge.

\section{Agradecimentos}

Agradeço ao Conselho Nacional de Desenvolvimento Científico e Tecnológico (CNPq) pelo financiamento da pesquisa.

\footnotetext{
${ }^{1}$ Verissimo, E. Olhai os lírios do campo. São Paulo, SP: Companhia das Letras, 2005.

${ }^{2}$ Torresini, E.R. História de um sucesso literário: Olhai os lírios do campo de Erico Verissimo. Porto Alegre, RS: Literalis, 2003.

${ }^{3}$ Hemeroteca Digital Brasileira da Biblioteca Nacional: A cruz, 1938. Alagoas, mensário ilustrado, 1938. Diário de Notícias, 1938-1939. Diretrizes, 1939. Dom Casmurro, 1939-1940. Fon Fon, 1938. Jornal do Brasil, 1938-1939. O Dia, 1938-1949. O Imparcial, 1938. O Jornal, 1938.
} 